\title{
About sociolinguistics and its problems
}

\author{
Salikhova Renata Bulatovna ${ }^{1}$ \\ ${ }^{1}$ Teacher of Karshi school №9 \\ Charos Uralova Ganisherovna ${ }^{2}$ \\ ${ }^{2}$ Student of SamSIFL \\ Rajabova Shaxnoza Olbayevna ${ }^{3}$ \\ ${ }^{3}$ Teacher of school №34 Koson district of Kashkadarya
}

\begin{abstract}
This article is about sociolinguistics, but also about the problems in this discipline. This article also has the views of well-known scientists on sociolinguistics.
\end{abstract}

Key words: sociolinguistics, V.I.Belikov, G.Karri .

\section{Introduction}

Today, great changes are taking place in every field, every field, whether in medicine or medicine. Today, in a global context, this is in some ways a natural phenomenon. It should be noted that without a clear definition of any field, it is impossible to make clear and obvious changes in that field or science. The same is true of the concept of sociolinguistics, which we want to study. The history of this science goes back a long way. Before looking at its history, we can give a clear definition of this concept.

Sociolinguistics (lot societas - society and linguistics) - derived from the words linguistics, sociology (sociology), social psychology and ethnology, and the social nature of language, its social functions, the mechanism of influence of social factors on language and language. It is a scientific-theoretical field that studies a wide range of problems related to its role in society. Therefore, it is clear that this concept is broad and there is a need for this science in every field.

In this regard, it is necessary to give a description of the great Russian sociolinguist V.I.Belikov in the field of sociolinguistics:

As mentioned above, the history of this science goes back a long way, but in the 20-30s of the last century, sociolinguistics began to emerge as a certain science of linguistics. In this period, the role of language in the development of life in social relations The importance and relevance of the science of sociolinguistics in the study of the formation of language and society, as well as in the emergence of trends, became clear.

\section{Main part}

It should be noted that the emergence of sociolinguistics in this period took place in such a way that the factors that cover issues related to the development of society in life led to the emergence of language theory. In particular, language knowledge and perception in solving social problems In short, the development of sociolinguistics plays an important role in the development of society.

The modern term "sociolinguistics" was first introduced to science in 1952 by the American sociologist G.Karri 1952. Another sociologist, J.A.Fishman's "Readings in the Society of Language" There are also descriptions of this theme in the plaid. In the preface to the book, J.A. Fishman draws attention to the use of the terms "sociology of language" and "sociolinguistics" as synonyms.

In sociology, as in other sciences, a number of problems can be highlighted. They help to form a correct picture of people who follow this scientific discipline.

One of the important things that scientists are studying is the social stratification of language, that is, the study of the different variations of a single language at all structural levels. The emergence of different variants of a single language unit may be directly related to social conditions. It also includes the study of language change depending on a particular social situation (working with a group partner, talking to a person of high social status, ordering food in a cafe, etc.). The next important aspect of sociology the problem is "language and nation." In studying this problem, scholars refer to such a concept as the national language, that is, the civil language of a particular nation. In addition to the state language enshrined in the Constitution, there are various dialects, functional styles, regional koins, and so on. They serve the process of communication between different social groups of people in different situations. Sociologists study the problem of the relationship between all variants of a single language in a given country. Social aspects of multilingualism (knowledge and use of at least one foreign language) and diglossia (a situation where there are several official languages in one region) . In studying this problem, scientists consider which categories of the population are multilingual. In the case of diglosia, which languages are used in which social group of the population.

\section{Conclusion}

The problem of verbal communication. In studying it, sociologists observe the communication of people belonging to different or one social group. The problem of language policy. What measures is the state taking to address the language problems in society? The global problem is the contradictions in these languages. Sociolinguists, on the basis of research, are trying to neutralize existing language conflicts between countries or to prevent possible ones. The problem of disappearing languages. 
Apparently, there are a wide range of problems in sociolinguistics, but all of them are related to the manifestation of language in society.

\section{References:}

\# Shvaytser A.D. Modern sociological language. Theory Problems. Methods. M., 1976 year

* Krysin L.P. Language in modern society. M., 1977 year

* Social and functional differentiation of literary languages. Edit version M.M.Guhman. M., 1977 year

* Shvaytser A.D., Nikolskiy L.B. Introduction to sociolinguistics. M., 1978

* Panov M.V. Sociophonetics. - in book: Panov M.V. Modern Russian. Phonetics. M., 1979

* Zvegintsev V.A. Social and linguistic in sociolinguistics. - Materials of the USSR Academy of Sciences. Literature and Languages Series, vol. 3. M., 1982 Vinogradov V.A., Koval A.I., Porkhomovskiy V.Ya. Sotsiolingvistik tipologiya. - Kitobda: G'arbiy Afrika. M., 1984 yil

* Krysin L.P. Sociolinguistic aspects of modern Russian language learning. M., 1989

* V.K.Zhuravlev Dichron sociological language. Edit version. M., 1993

* Mechkovskaya NB . Social linguistics. M., 1996

\# Belikov V.I., Krysin L.P. . Sociolinguistics. M., 2000 